\title{
Analytical study of Iberian Iron Age stone sculptures and their surface marks
}

\author{
R. Fort, ${ }^{1}$ C. Vazquez-Calvo ${ }^{1}$, T. Chapa $^{2}$, M.I. Martínez-Navarrete ${ }^{3}$, M. Belén ${ }^{4}$ \\ 1 Instituto de Geociencias (CSIC-UCM) \\ 2 Departamento de Prehistoria. Facultad de Geografía e Historia (UCM) \\ 3 Instituto de Historia. Centro de Ciencias Humanas y Sociales (CSIC) \\ 4 Departamento de Prehistoria y Arqueología (Universidad de Sevilla)
}

\begin{abstract}
The Archaeological Museum of Jaén's sizeable collection of Iron Age sculptures, dating from the fifth century BCE, were all found at Cerrillo Blanco de Porcuna, a site in the Spanish province of Jaén. The collection comprises over 40 statues and hundreds of fragments. Incisions recently identified on some of these sculptures have been interpreted to be sculptors' marks. The present archaeometric study conducted with a 3D roughness meter showed that the marks on several of the sculptures analysed were made with the same type of tool and the same engraving technique. While the graphological differences denote different authorship, they would appear to have been made in the same workshop. The morphological differences observed in the lines analysed on other sculptures are interpreted to indicate the use of other types of tools and engraving techniques.
\end{abstract}

\section{KEYWORDS}

Iberian sculpture, Iron Age, sculpture workshops, graphology, limestone, roughness

\section{INTRODUCTION}

The ancient Iberians, like the Greeks and Etruscans, used monumental stone sculptures in their sanctuaries and necropolis. Such use of sculptures by these three Mediterranean cultures was approximately contemporary, beginning in the early sixth century BCE and ending with the progressive adoption of iconography and the techniques introduced by the Romans after the third century BCE. The Iberian art form is much more scantly known than the other two, however. The main reasons for that state of affairs are the physical distance separating Iberian civilisation from the centre of Hellenic culture, the "modest" standard of many of the known works and the fact that the material used was not marble, but invariably limestone. As a result of the diffusionist and aesthetic focus that characterised specialised research for many years, these considerations relegated the study of Iberian sculpture to a futile attempt to compare it to its alleged Greek references. With the advent of new methodologies and the surprising discoveries of recent years, that situation is now changing (Ruiz and Molinos 1998). 
Iberian sculpture has peculiarities of its own. Its creative processes denote a strong oriental influence traceable to Phoenician colonisation, which was characterised by stable settlements that first appeared on the Iberian coasts at the end of the ninth century BCE and lasted through the Carthaginian period from the early sixth century BCE onwards. These processes merged with the traditions from eastern Greece, which reached the peninsula from the Phocaean colonies at Massalia, Emporion and other Mediterranean trading ports. The result is a highly original production, adapted to local tastes forged during centuries of close interaction with the Phoenician world, although in certain iconographies clearly reflect Hellenic influence.

Analytical techniques have barely begun to be used in this field. Data are only available for a few well known sculptures such as the Lady of Elche (Luxán et al. 2005) or the Lady of Baza (Gómez et al. 2010). The fact that all the known pieces were sculpted in limestone, which can be found in abundance all across Mediterranean Iberia, has contributed to the widespread acceptance of the unconfirmed opinion that the artists worked with strictly local materials. This, in turn, has translated into the very limited application of petrographic analysis to precisely identify the places where the stone was quarried (Belén et al. 2009; Gagnaison et al. 2007). A further difficulty is that no analytical information relevant to research has been forthcoming from the conservation and restoration work performed on the sculptures, whose results are to be found as mere observations in internal government and museum reports. The present study aims to reverse this trend, undertaking new lines of analytical research that include stone characteristics, surface treatments and post-deposition alterations. The findings will be relevant to both research and the conservation and exhibition of the pieces.

The study focuses on the exceptional sculptural find discovered at the Iberian site known as "Cerrillo Blanco", located north of what is now the village of Porcuna (central Andalusia) (Fig. 1). The uncontrolled discovery in 1975 of a few pieces later bought by the director of the Jaén Museum triggered archaeological interest (González Navarrete and Arteaga 1980). A total of 1,274 fragments of sculptures were recovered in the subsequent digs, some of which could be used to partially recompose around 40 figures now on exhibit at the museum, while the rest of the fragments are in storage. Negueruela (1990), who studied some of the groups in detail, estimated that over 60 sculptures had been deposited at the site.

Most of these free standing, nearly full scale figures, represent real or imaginary animals (wolves, lambs, eagles, bulls, griffins, sphinxes) or human beings. Some express the static attitude characteristic of sanctuary statues, while others depict dynamic scenes associated with combat or hunting (Olmos 2002). Despite the variety of subject matters and types of figuration, a common working style can be identified in all the statues, indicating the presence of a single shop where a number of sculptors worked under the orders of a master.

The site stratigraphy shows that the upper part of the hill was first used in the seventh century BCE as a Tartessian burial grounds. The limestone sculptures found in 1975, in all likelihood sculpted in the mid-fifth century BCE, were deposited in the latter years of that century in a trench dug around the area occupied by the tombs. The pieces found were 
broken and incomplete, but since they were buried and covered over with large stone slabs, they are in an excellent state of conservation. Some, however, were left on the surface, either at that time or as a result of subsequent ploughing. In the former case, they were eventually used as stone coverage for funerary urns in a small fourth to third century BCE necropolis sited on the north end of the hill. In any event, the sculptures not protected inside the trench show much greater surface erosion, facilitating the comparison between open and closed environments.

The fragmentation of the sculptures denotes intentional destruction. This is generally interpreted as an attack against the symbolism of the figures and the persons who commissioned the monument, but parallels can be found in other Mediterranean cultures, which also buried sculptures pertaining to sanctuaries that were abandoned or relocated (Zofío and Chapa 2005; Edlund-Berry 1994).

One of the most striking aspects of these pieces, in particular the animal figures, is the presence of different types of surface incisions. Some are very thin and represent elaborate geometric signs. While they are located on visible areas of the sculptures, they are so slender that most had not been detected in prior studies and very likely went equally unnoticed in the Iberian age. They might be interpreted to be sculptor's marks or a symbol signifying completion of the sculpting process (Chapa et al. 2009). While the Iberians used writing on occasion for certain documents, no sculpture has been found with an inscription that identifies the statue or includes the artist's or subject's name. According to the above authors, piece E46 of the collection might be an exception, although the "signature", which includes a simple human face, may also have been engraved not when the piece was made, but on one of the fragments after it was destroyed. The second type of incisions is wider and deeper and consequently perfectly visible to the naked eye. They are found on the surface of some pieces, where they formed part of the subject, representing superficial wounds caused by a confrontation between animals, for instance.

\section{METHODOLOGY}

To date, incisions have only been found on pieces representing animals. The statues whose marks (Chapa et al. 2009) were selected for study were "Wolf Attacking Lamb" (E10), "Hunter with Hare" (E35) and a fragment with a human face (E46). The snake tooth scars on the Griffin's back in the "Griffin and Snake" (E09) (Fig. 2) were also measured.

In addition to the above, the study included a fragment (E00) (Fig. 2) found in June 2010 on the occasion of the dig presently underway at the Cerrillo Blanco de Porcuna archaeological site (Fig. 1). The fragment in question had been re-used to lid an urn containing bones from a fourth or third-century BCE cremation. Therefore its position was different from the sculptures found in 1975 and taken to the Archaeological Museum of Jaén. This piece was used to verify the incision technique in the so-called sculptors' signatures. After it was cut, several incisions were made on its surface with a $0.70-\mathrm{mm}$ punch for comparison to the marks detected on the sculptures. These laboratory incisions were made by holding the punch in a vertical position and drawing it across the surface under constant pressure. The marks were made on samples dried after having been 
submerged in water for 12 hours, in keeping with a technique used to facilitate stone cutting.

Petrographic and mineralogical analysis

The petrographic analysis of the stone materials was performed on an Olympus BX51 polarized optical microscope fitted with an Olympus DP12 digital camera. The carbonate rocks were partially stained with alizarin red to distinguish the calcitic from the dolomitic components.

The mineral phases were determined by XRD of the powder fraction from the entire sample on a Philips Analytical PW 1752 diffractometer operated at $40 \mathrm{kV}$ and $30 \mathrm{~mA}$, equipped with a copper K-alpha anode tube, graphite monochromator and PC-ADP Diffraction software.

The petrographic analysis was conducted on the fragment removed from the site in June 2010 .

Surface hardness

Hardness was determined on the aforementioned stone fragment on a TIME Technology Europe MicroVickers Hardness THV 501E microdurometer. Ten measurements were taken of the depth of the indentation made on the sawn surface of the stone with a pyramidal diamond punch having a $136^{\circ}$ angle at the vertex between sides. The findings were used to calculate the Vickers scale hardness number (ASTM C1327-03).

Vickers hardness $(\mathrm{VH})$ is defined as $1.854 \mathrm{P} / \mathrm{A}$, where $\mathrm{A}$ is the area of the mark and $\mathrm{P}$ the load applied. The load applied to make the incision was $2.94 \mathrm{~N}$ for 20 seconds.

Colour analysis

A MINOLTA CM-700d spectrophotometer operating in SCE (saturated calomel electrode) mode was used to measure CIELAB (Commission Internationale de l'Eclairage, CIE 1986) colour parameters $\left(\mathrm{L}^{*}, \mathrm{a}^{*}\right.$ and $\left.\mathrm{b}^{*}\right)$ under a D65 light source. $\mathrm{L}^{*}$ denotes lightness, $\mathrm{a}^{*}$ is the red-green scale indicator (the more positive the value, the redder the specimen and the more negative, the greener) and $b^{*}$ the blue-yellow scale indicator (the more positive the value, the yellower the specimen and the more negative, the bluer). The same analyser was used to measure the yellowness (YI) and whiteness (WI) indexes as defined in the ASTM 313-76 system (ASTM, 2000). 
Colour measurements were taken on the surface of each of the sculptures selected and on exhibit in the museum, as well as on the fracture surface of all the pieces.

The fragment taken from the site was also measured for colour on the engraved surface, but also along the fracture and internally by means of an incision $4 \mathrm{~cm}$ deep, to determine the natural colour of the stone from which the figures were sculpted.

Roughness measurements

Roughness was measured with a TRACEit optical surface (OSR) roughness tester. This portable, white light analyser takes roughness measurements non-destructively, without touching the sample surface, and produces 3D topographic maps showing roughness on a microscale (microns). The measuring field was $5 \times 5 \mathrm{~mm}$ and the resolution along both the $\mathrm{Z}$ and the $\mathrm{X} / \mathrm{Y}$ axes was $2.5 \mu \mathrm{m}$. A total of 2000 data items were collected along the latter. The mean values for the roughness parameters, $\mathrm{Ra}, \mathrm{Rq}$ and $\mathrm{Rz}$, were obtained from the 25$\mathrm{mm}^{2}$ 3D microtopographic maps. These parameters were calculated with software built into the analyser further to the provisions of international, European and German standard DIN EN ISO 3274:1996.

These parameters are defined in the International Organization for Standardization standard 4287 as follows.

-Ra is the arithmetic mean of the absolute values of the deviations from the mean.

-Rq is the square root of the deviation from the mean, also known as RMS (root mean square) roughness, i.e., the square root of the mean roughness.

$-\mathbf{R z}$ is the sum of the vertical distances between the five highest peaks and five deepest valleys in the sample.

In addition to these parameters, the greatest vertical distance between the peak and valley in each profile (Hp) was likewise found. Two-dimensional profiles with a maximum length of $5 \mathrm{~mm}$ were also possible, with detectable variations in height of up to $1 \mathrm{~mm}$.

\section{RESULTS}

The stone in Porcuna sculptures

The Iberian sculptures from Cerrillo Blanco at Porcuna were carved from limestone classified as fine-grained $(<1 \mathrm{~mm})$ biocalcarenite, comprising primarily globigerina (Espinosa et al. 2001).

The sculpture fragment (E00), sampled in the same location, was classified as a packstone (Dunham, 1962), with a grainy texture and a micritic matrix. The rock was found to be 
made up primarily of globigerina particles ranging in size from 0.1 to $0.5 \mathrm{~mm}$, along with a much smaller proportion of other foraminifers and molluscs. An occasional gastropod shell was also identified. The rock had a low concentration of terrigenous elements, which consisted mainly of quartz. These components were observed to be cemented with sparry calcite, whose drusy crystals lined the surface of the pores. Brownish-yellow glauconite particles up to $4 \mathrm{~mm}$ in diameter and visible to the naked eye were also detected on the surface of some of the sculptures. The rock proved to be highly porous (> $20 \%$ ) (Fig. 3).

Viewed under a binocular microscope, the surface of this fragment closely resembled the surfaces of the museum sculptures and fragments, and the size, shape, distribution and percentage of globigerina particles was similar in the two types of pieces, as shown in figure 4. Nonetheless, while the fragment from the site, which had been recently sectioned, exhibited no alterations, the sculptures showed signs of dissolution and re-precipitation.

With a mean hardness of $43 \pm 29$ (a value similar to the hardness reported by Espinosa $e t$ al. (2001) using the Brinell method), the stone was readily engravable, so the surface incisions could be drawn as continuous lines with fairly little pressure.

\section{Colour parameters}

Information on the natural colour of the stone from which the sculptures were carved is of particular relevance for defining the geological and geographic origin of these materials (Fort et al. 2002; Gómez Heras \& Fort. 2004).

The colour of the piece taken from the site, whose surface reflected the natural colour of the stone used for the sculptures, had a lightness $\left(\mathrm{L}^{*}\right)$ of 77 units, $\mathrm{a}^{*}$ and $\mathrm{b}^{*}$ values of 2.8 and 15.5 , respectively, and a yellowness index of nearly 27 . These values were close to the surface colour values for the museum sculptures (Table 1).

Both the engraved and fracture surfaces of the piece taken from the dig site differed from the natural colour of the stone due to soiling while it was underground. Prior to being placed on display, the museum pieces would have been characterised by the same colour. At the time, the entire surface of all the sculptures must have been cleaned using the same method on the carved areas and the fracture surfaces, for their colour characteristics were similar.

The colour difference $\left(\Delta \mathrm{E}^{*}\right)$ between the natural stone and the surface of the sculptures on exhibit was 3.8, a value that denotes change imperceptible to the human eye. According to these findings, the sculptures analysed have not been exposed to aggressive conditions that would favour the formation of patinas due to natural ageing.

Surface roughness in the sculptures 
The sculptures exhibited several types of decay, including dissolution, chipping and cavities, among others. Dissolution was one of the more important processes, for the result, the enhanced presence of globigerina particles, whose skeleton is more difficult to dissolve, gives rise to a very characteristic surface (Fig. 4b, c). As a rule, where no significant decay took place, the sculptures had a polished surface with low roughness index values. The mean values of the roughness parameters for the sculptures studied were: $\mathrm{Ra}=7.3 \pm 0.8 \mu \mathrm{m}, \mathrm{Rq}=9.3 \pm 0.8 \mu \mathrm{m}, \mathrm{Rz}=30.5 \pm 2.6 \mu \mathrm{m}$. The mean for Hp was $135.8 \pm$ $12.3 \mu \mathrm{m}$.

The mean roughness parameters in the non-decayed areas of the sculptures are given in table 2. Piece E46 had the lowest roughness indices. By contrast, the areas where decay was most intense due to exposure to the atmospheric elements or burial in more aggressive media had the highest values. The values for the piece taken from the archaeological site, for instance, were: $\mathrm{Ra}=11.5 \pm 1.9 \mu \mathrm{m} ; \mathrm{Rq}=14.3 \pm 2.1 \mu \mathrm{m} ; \mathrm{Rz}=47.7 \pm 6.9 \mu \mathrm{m}$. The Hp was $182 \mu \mathrm{m}$.

Figure 5 and 6 show the 3D microtopographs of the area containing the incisions on the sculptures and the profiles $X-X^{\prime}$ ' cutting the incision lines (A-A' and B-B'). Points where $\mathrm{X}-\mathrm{X}$ ' lines cut A-A' lines and B-B' lines are marked with "a" and " $\mathrm{b}$ " respectively. The profile $\mathrm{X}-\mathrm{X}$ ' for sculpture $\mathrm{E} 46$, in a 5-mm square cross-section, was smoother than in the other sculptures. Over half of the X-X' profile consisted of small peaks and valleys no larger than $15 \mu \mathrm{m}$. Variations in the base level, with $\mathrm{Z}$ values of $70 \mu \mathrm{m}$, were observed only at the beginning of the profile. In sculpture E10, the profile $X-X^{\prime}$ consisted of a series of plateaus interrupted by narrow valleys. The plateaus represented the polished surface of the sculpture, and the valleys the areas where the globigerina skeletons protruded outward from the pores. The morphology of these valleys differed in width and depth depending on the orientation of the cross-section with respect to the globigerina. The deepest and broadest valleys would logically concur with the largest globigerina particles or particles sectioned across the largest diameter of the fossil. The roughness parameters associated with these profiles (X-X') were similar in the two sculptures. For sculpture E46 the values were: $\mathrm{Ra}=4.7 \mu \mathrm{m} ; \mathrm{Rq}=6.0 \mu \mathrm{m}$; and for sculpture $\mathrm{E} 35$ : $\mathrm{Ra}=5.7 \mu \mathrm{m} ; \mathrm{Rq}=7.3 \mu \mathrm{m}$; and $\mathrm{Rz}=22.8 \mu \mathrm{m}$.

A comparison of these values to the parameters for the site fragment showed roughness to be greater in the latter $(\mathrm{Ra}=14.8 \mu \mathrm{m} ; \mathrm{Rq}=17.8 \mu \mathrm{m} ; \mathrm{Rz}=61.6 \mu \mathrm{m})$.

Another difference between the profiles for the sculpture surfaces and the surface of the site fragment was depth. This value was nearly double in the fragment $(70-80 \mu \mathrm{m}$ compared to $145 \mu \mathrm{m}$ ), which had been buried in aggressive media. The findings showed, then, that decayed stone exhibited very different profile and roughness patterns (Fig. 8).

Sculptors' marks: dimensional characteristics

The roughness parameters on the parts of the sculptures bearing sculptors' marks were higher than on the areas with no incisions (Table 2). These variations were not always sufficiently significant, due to the high standard deviations involved, to distinguish these 
areas as anomalies, with the exception of the marks on sculpture E46, where the differences were sizeable.

Measurements were taken in areas measuring $50 \mathrm{~mm}^{2}$, in which anomalies such as incisions may be mimicked by other decay processes. Furthermore, since the mean value was found for the whole area where the mark was located, even though the incision itself may have accounted for no more than $10 \%$ of the total, its effect on surface roughness for the entire area was logically small. In addition, variations in roughness may also be due to other, naturally-induced events, such as cracking or dissolution. These procedures must be viewed, then, as archaeometric techniques which are useful to characterise the origin of the processes detected only when applied in conjunction with supplementary methods. Therefore, the mean values for the roughness parameters covering the entire surface can not always differentiate the processes underway and these results must be supplemented with roughness profiles.

Three-dimensional microtopographic mapping of the sculpture surface reflected the form and other properties of these incisions in the stones very clearly (Fig. 5). The lines (A-A' and B-B') were observed to be very straight, although in some cases, such as on the Hunter with Hare (E35), one was slightly skewed. The depth was not the same for all the marks and some, such as on the aforementioned sculpture, were barely visible.

The depth and width of the marks on each of the sculptures analysed are given in Table 3. In the sculptors' signatures, the width of the incisions ranged from 0.63 to $0.73 \mathrm{~mm}$, and the depth from 100 to $150 \mu \mathrm{m}$.

One of the kind lines, the B-B' was shallower and generally narrower and less clearly defined than the rest. This can be seen in figure 7 , which shows the cross-sectional profile of these incisions in the stone.

The roughness profile mapped along the entire length (Fig. 5, 7) of each mark showed that in the lines designated B-B' (E35-B and E10-B profiles) in Hunter with Hare (E35) and Wolf and Lamb (E10) were not only less deep but also less rough. This was an indication that the line was made under the same pressure, whereas in the A-A' lines (E35-A and E10-A profiles), the depth was greater and the topography less regular, generating peaks and valleys that may be attributed to one of two possible causes:

- higher pressure in these areas, generating asymmetric valleys in the direction of travel of the tool; - detachment of rock constituents (globigerina particles).

The elongated circular morphology of these valleys was similar to the notches left when the fill in globigerina chambers dissolves or detaches. Nonetheless, the fact that as a rule they were centred in the groove and all of similar size would be an indication that they were the result of the first of the above two causes. Globigerina particles vary in size from 
0.1 to $0.5 \mathrm{~mm}$. Globigerina particles were also detected on the polished surface of the site piece with the Traceit tester, although here they ranged in size from 0.1 to $0.3 \mathrm{~mm}$. In other words, they were smaller than the notches in the grooves which, like the grooves themselves, were 0.6 to $0.7 \mathrm{~mm}$ wide. Therefore, although the notches may have been widened or deepened by the presence of globigerina particles, this difference in size were more likely due to variations in the pressure exerted on the tool. No such notches were observed in the shallower marks that were generated with less pressure.

Another important factor observed in the sculptors' signatures on pieces E10 and E35 was that the depth of the marks tended to decline toward the end of the line, which began at the vertex where the two lines converged. The tool, then, was dragged away from the vertex with slight variations in pressure, which generated greater depths in some points in the incision.

The A-A' line in sculpture E46 was very different, both as regards its symbolism and the engraving method used. The incisions in this "sculpted sketch" were similar in depth to the A-A' lines in other sculptures, but must have been made with another tool, for the width of the incision was $0.5 \mathrm{~mm}$. The longitudinal profile of one of the lines on this piece was very different from the topography in the sculptors' signatures. The incision technique must have been different, as denoted by the use of a narrower $(0.5 \mathrm{~mm})$ tool and different pressure. Moreover, given the dissimilarity of its graphology, it must have had a different meaning.

The characteristics of the sculptor's lines depicting snake tooth scars on the griffin's back (E09) also differed. In this case they were piece-specific: the sculptor made two parallel grooves spaced at about $3.5 \mathrm{~mm}$, each about $240 \mu \mathrm{m}$ deep and $1.2 \mathrm{~mm}$ wide. They were consequently deeper and wider than the incisions described above (Fig. 7). The longitudinal topography of these lines also differed from what was observed in the preceding marks. Here protrusions were detected, some slanted toward the direction of the sculpting tool, as shown in profile E09 A-A'. The technique used to engrave the scar may have involved dragging and tapping.

The marks made by the research team (Fig. 8) with a $0.7 \mathrm{~mm}$ punch resulted in a line whose mean depth in moist stone was $190 \mu \mathrm{m}$ and in dry stone, $180 \mu \mathrm{m}$. The differences between the two were not significant and the values were similar to the results observed for lines A-A' in the marks on the sculptures. The width of the marks made for this study was $0.7 \mathrm{~mm}$, similar to the width of the lines on the sculptures. The sole difference observed between the graphology of the lines made for the study and the originals on the sculptures was that the edges of the groove in the former were raised (Fig. 8), forming a shoulder. That this was either imperceptible or discontinuous along the line in E10 (Fig. 6) may have been due to the time-induced decay on the surface of the sculpture.

\section{CONCLUSIONS}


-The sculptures analysed with linear graphics contained incisions interpreted to be sculptors' marks or signatures. Despite being barely visible marks, the methodology has allowed to determine they were made with the same type of tool and the same engraving technique. Its application on a wider sample may lead to identify different signatures and accumulate information about how the ancient workshops finished up their works.

-The presence of notches inside these signature lines may have been due to the exertion of greater pressure on the punch.

-These pieces, with polished surfaces and clearly defined incisions, were not exposed to decay in outdoor environments, or if they were, it was only for a short period of time, because no dissolution was observed. Other sculptures or the restored fragments of these same sculptures did exhibit such processes, however, an indication that they were very likely buried under different circumstances than the parts analysed.

-The technique used to measure the surface roughness of the sculptures was able to distinguish the characteristics of the tool used to make the incisions appearing on these pieces. The two sculptors' signatures were found to have been made with the same type of punching tool with a 0.7 -mm thick tip.

-It also provided insight into the working technique, since one of the lines was observed to be consistently deeper than the other $(a>b)$ and both were found to start at the vertex where they converged, for the depth tended to decline outward from that vertex.

-The incisions were made by dragging the punch across the surface of the stone.

-The line appearing on E46 was narrower $(0.54 \mathrm{~mm})$ and very uniform both in width and depth. The technique used was to make the incision and then drag the punch.

-The two grooves representing snake bites on sculpture E35 were parallel and spaced at 3.5 $\mathrm{mm}$. The tool used was larger in diameter $(1.20 \mathrm{~mm})$ than in the sculptors' signature marks, and the depth of the two grooves was similar, at around 240 microns.

-Lastly, the findings confirmed the suitability of the method consisting of a roughness tester and 3D microtopographic mapping to draw longitudinal and transverse profiles for characterising and differentiating the incisions detected on the sculptures.

\section{ACKNOWLEDGEMENTS}

This research was funded under Project HUM2007/60074, Geomaterials Programmes (S2009/MAT-1629) and CONSOLIDER-TCP (CSD2007-0058), and by the Complutense University of Madrid research group: Alteration and Conservation of Heritage Stone (ref. 921349), which forms part of the CEI-Moncloa International Excellence Campus. The authors wish to thank the Archaeological Museum of Jaén for its assistance in this study. . As well as the archaeological company "Arq13", which has allowed us to review the 2009 excavation at the site. We would like also to express or gratitude to the anonymous reviewers whose preceptive comments have helped to improve the quality of the paper.

\section{REFERENCES}

ASTM (American Society for Testing and Materials), 2000, E313-00 Standard Practice for Calculating Yellowness and Whiteness Indices from Instrumentally measured Color Coordinates, West Conshohocken, Pennsylvania. 
ASTM (American Society for Testing and Materials), C1327-03, Standard Test Method for Vickers Indentation Hardness of Advanced Ceramics, 465-472.

Belén Deamos, M., Vázquez Calvo, C., Fort González, R., and Chapa Brunet, T, 2009, The Firtst Evidence of a Tartessian Stone Sculpture: a Fragmentary Cult Image from Carmona (Seville, Spain), in Interdisciplinary Studies on Mediterranean Ancient Marble and Stones). Proceedings of the VIIIth International Conference of the Association for the Study of Marble and Other Stones used in Antiquity (ASMOSIA). Aix-en-Provence. 12-18 juin 2006 (ED, Jockey, Ph): LEUKOS LITHOS. Maisonneuve \& Larose. 243-254, Maison Méditerranéenne des Sciences de l'Homme, Paris.

Chapa, T., Belén, M., Martínez-Navarrete, M. I., Rodero, A., Ceprián, B., and Pereira, J., 2009, Sculptor's signatures on Iberian stone statues from Ipolca-Obulco (Porcuna, Jaén, Spain), Antiquity 83, 723-737.

Commission Internationale de l'Eclairage (CIE), 1986. Colorimetry, 2nd edition. Bureau central de la CIE, Paris

Dunham, R. J., 1962, Classification of carbonate rocks according to depositional texture, in Classification of Carbonate Rocks (ed. Ham W.E.). American Association Petroleum Geologists. Mem. 1, 108-121.

Edlund-Berry, I. E. M., 1994, Ritual destruction of cities and sanctuaries: the "unfounding" of the Archaic monumental building at Poggio Civitate (Murlo)", in Murlo and the Etruscans. Art and Society in Ancient Etruria (Eds, de Puma, R.D. and Penny Small, J.), 16-28, The University of Wisconsin Press, Madison.

European and German standrad DIN EN ISO: 3274:1996, Geometrical Product Specifications (GPS) - Surface texture: Profile method - Nominal characteristics of contact (stylus) instruments (ISO 3274:1996).

Espinosa, J., Samero, M., Gutiérrez Montero, F.,2001, Esculturas del Cerrillo Blanco de Porcuna (Jaén): Caracterización de los materiales y evaluación de productos de tratamiento, in III Congreso Nacional de Arqueometría (Eds, Gómez Tubío, B., Respaldiza, M.A. and Pardo, M.L.), 50, 49-58, Secretariado Publicaciones Universidad de Sevilla y Fundación El Monte, Serie Abierta, Sevilla.

Fort, R., Bernabéu, A., García del Cura, M.A., Ordoñez, S., Lopez de Azcona, M.C., Mingarro, F., 2002, Novelda Stone: a stone widely used within the spanish architectural heritage. Materiales de Construccion 52, 266, 19-32 
Gagnaison, C., Montenat, Ch., Barrier, P., Rouillard, P., 2007, L'environnement du site ibérique de La Alcudia et les carrières antiques de la Dame d'Elche (Province d'Alicante, Espagne). Archéosciences 31: 59-78.

Gómez-Heras, M., Fort, R., 2004, Location of quarries of non-traditional stony materials in the architecture of Madrid: The Crypt of the Cathedral of Santa María la Real de la Almudena. Materiales de Construccion 54, 33-49

Gómez, M., Navarro, J.V., Martín de Hijas, C., del Egido, M., Algueró, M., González, E. and Arteaga, Á., 2010, La escultura de Baza: materias, pátinas y policromía, in La Dama de Baza. Un viaje femenino al más allá, Actas del Encuentro Internacional (Museo Arqueológico Nacional, 27-28 de noviembre 2007) (eds. Chapa, T. and Izquierdo, I.), 103118 , Centro de Publicaciones. $\mathrm{M}^{\mathrm{o}}$ de Cultura, Madrid.

González Navarrete, J. and Arteaga, O., 1980, La necrópolis del Cerrillo Blanco y el poblado de Los Alcores (Porcuna, Jaén), Noticiario Arqueológico Hispano 10, 185-217.

Luxán, M. P., Prada, J. L., and Dorrego, F., 2005, Dama de Elche: pigments, surface coating and stone of the sculpture, Materials and structures 38 (277, April), 419-424.

Negueruela, I., 1990, Los monumentos escultóricos ibéricos del Cerrillo Blanco de Porcuna (Jaén). Ministerio de Cultura, Madrid.

Olmos, R., 2002, Los grupos escultóricos del Cerrillo Blanco de Porcuna (Jaén). Un ensayo de lectura iconográfica convergente, Archivo Espańol de Arqueología 75, 107-122.

Ruiz, A. and Molinos, M., 1998, The Archaeology of the Iberians. Cambridge University Press, Cambridge.

Zofío, S. and Chapa, T., 2005, Enterrar el pasado: la destrucción del conjunto escultórico del Cerrillo Blanco de Porcuna (Jaén), Verdolay 9, 95-120. 


\section{FIGURE CAPTIONS}

Figure 1. Location of the archaeological site of Cerrillo Blanco de Porcuna (Jaén, Spain)

Figure 2. Sculptures and marks studied; a) Hunter with Hare (E35), b) Griffin and Snake (E09), c) Wolf Attacking Lamb (E10), d) fragment with a human face (E46).

e) fragment (E00) found in June 2010, this fragment was buried and had been re-used to lid an urn containing bones from a fourth-century BCE cremation.

Figure 3. Appearance of the fragment of a sculpture taken from the Cerrillo Blanco de Porcuna site under petrographic microscope.

Figure 4. Surfaces of: (a) the Porcuna site fragment (E00); (b) sculpture E10; and (c) sculpture E46 under binocular microscope. Original image size: $25 \mathrm{~mm}^{2}$.

Figure 5. 3D microtopographs of the area containing the incisions on the sculptures. $X$-axis $(\mathrm{mm}), \mathrm{y}$-axis $(\mathrm{mm}), \mathrm{z}$-axis $(\mu \mathrm{m}) . \mathrm{X}-\mathrm{X}^{\prime}$ lines are profiles that cut the incisions on the sculptures whereas A-A' and B-B' lines are profiles following the incisions.

Figure 6. Cross-sectional roughness profiles ( $\mathrm{X}-\mathrm{X}^{\prime}$ lines) of sculptors' marks. $\mathrm{X}$-axis $(\mathrm{mm}), \mathrm{y}-$ axis $(\mu \mathrm{m})$. Points where A-A' lines and B-B' lines cut X-X' lines are marked with "a" and "b" respectively.

Figure 7. Longitudinal roughness profiles (A-A' and B-B' lines) of sculptors' marks. Xaxis $(\mathrm{mm}), \mathrm{y}-$ axis $(\mu \mathrm{m})$.

Figure 8. Cross-sectional roughness profiles of the two incisions made on the surface of the fragment (E00) found in June 2010 with a $0.70-\mathrm{mm}$ punch for comparison to the marks detected on the sculptures. Profile: $X$-axis $(\mathrm{mm}), y$ - axis $(\mu \mathrm{m}) .3 \mathrm{D}$ image: $X$-axis $(\mathrm{mm}), \mathrm{y}$ axis $(\mathrm{mm}), \mathrm{z}$-axis $(\mu \mathrm{m})$. A- $\mathrm{A}^{\prime}$ line is a profile that cut the two incisions.

Tables

Table 1 - Porcuna piece colour parameters

Table 2 - Roughness parameters of the sculptures studied

Table 3 -Characteristics of the marks on the sculptures 
Figure 1.

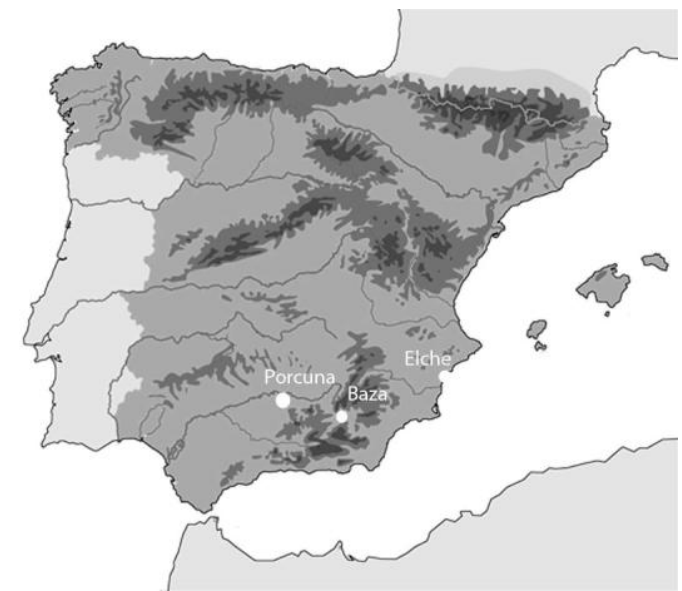


Figure 2.

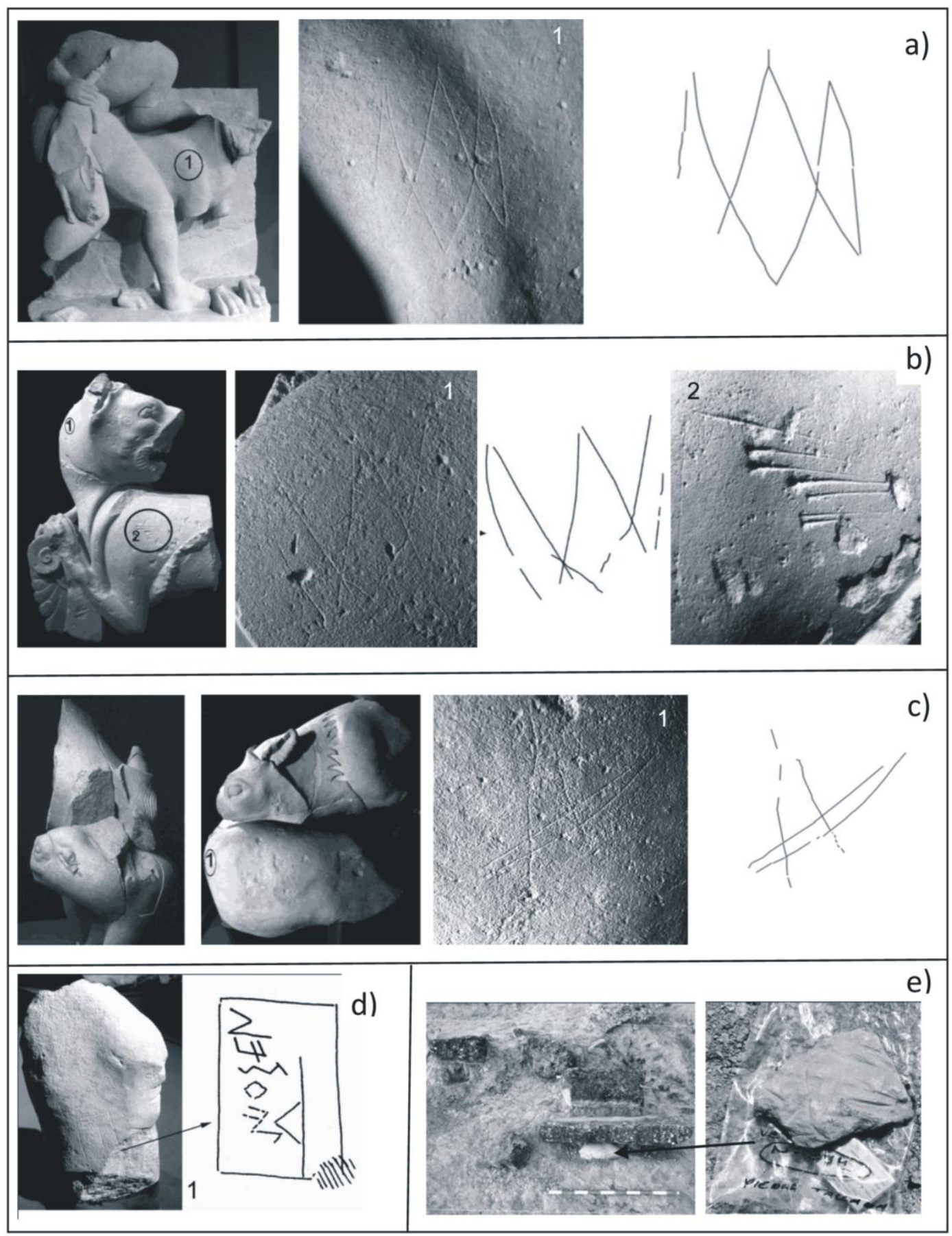


Figure 3.

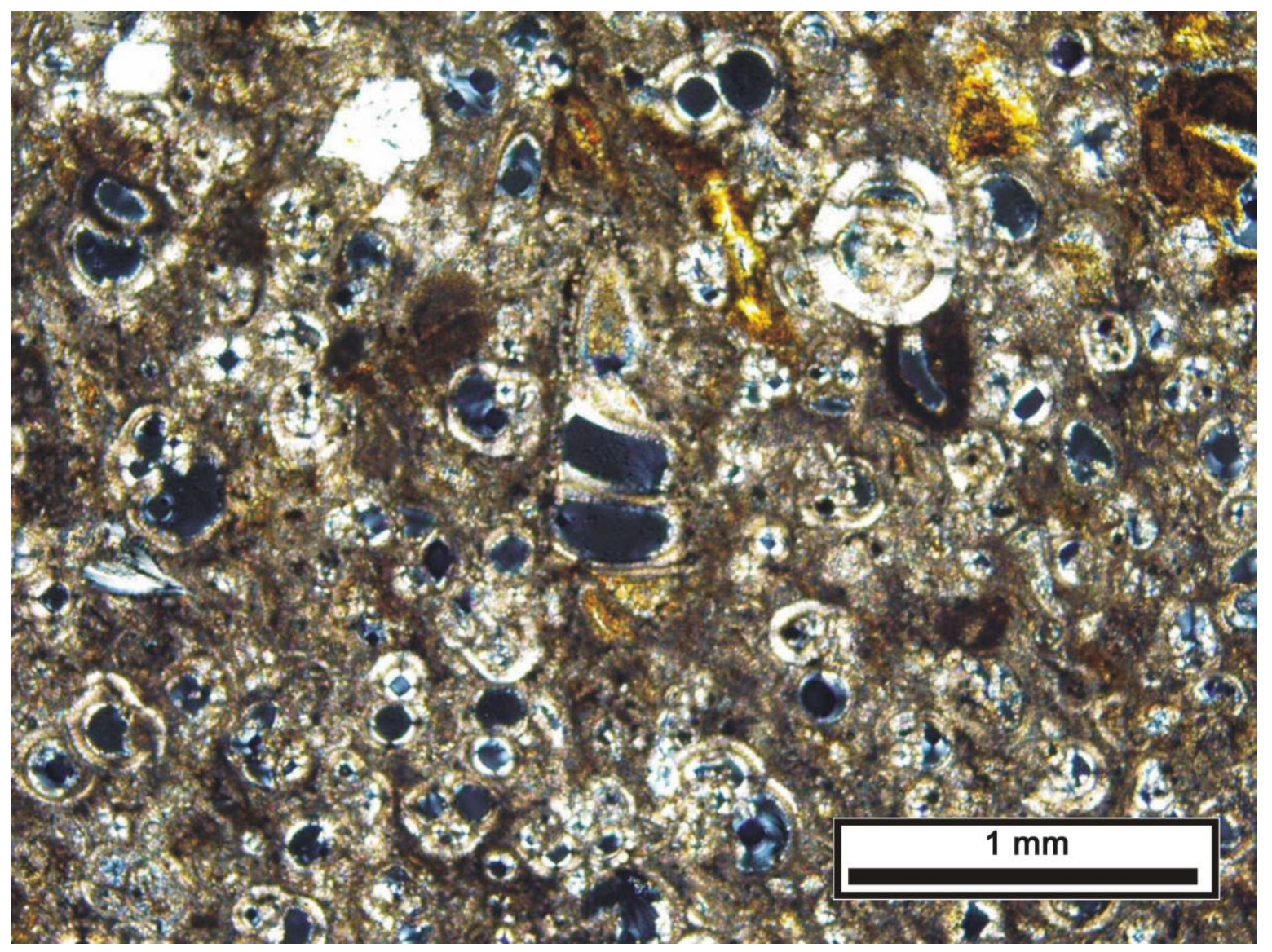

Figure 4.
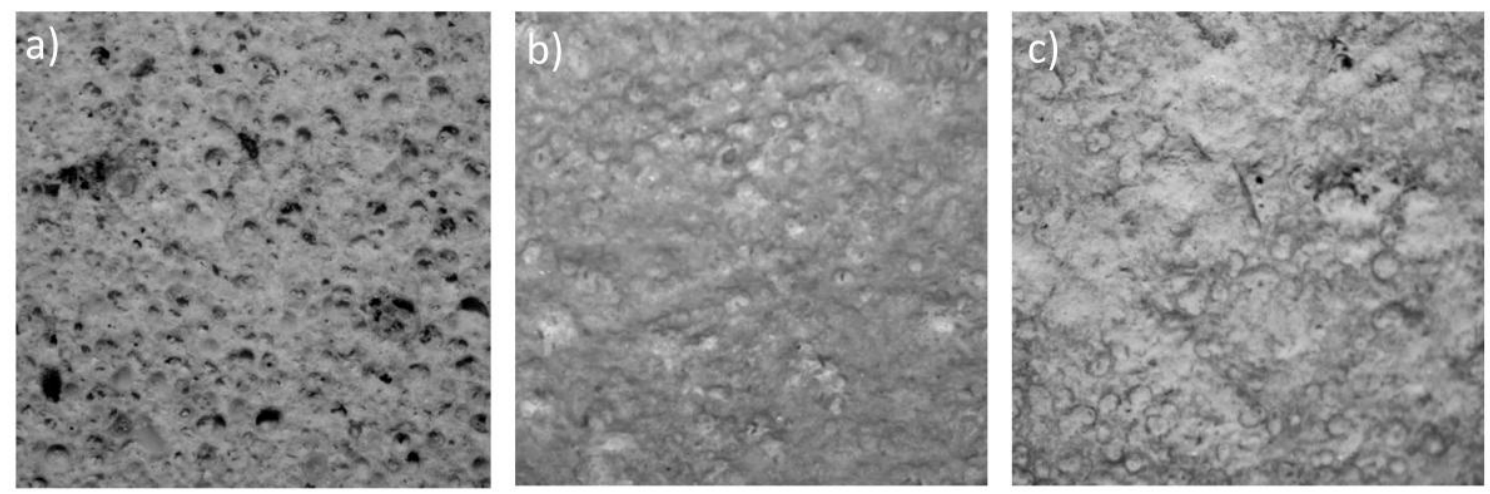
Figure 5.

\section{E09}

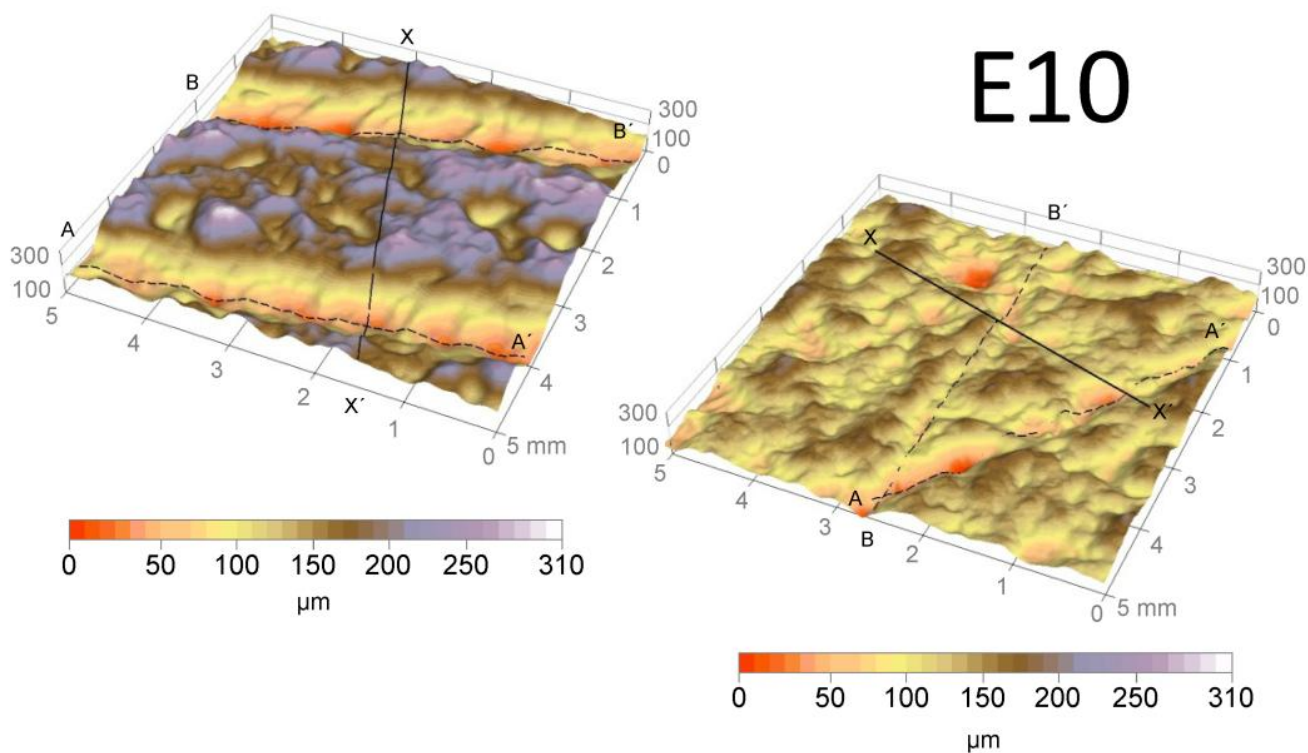

E35

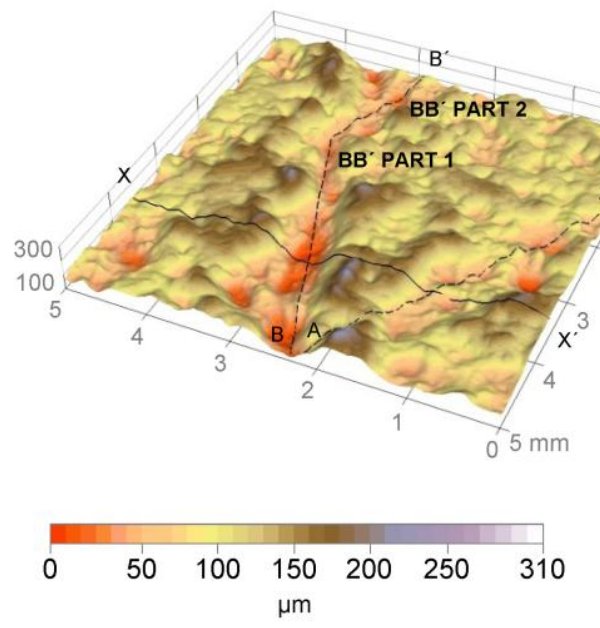

E46

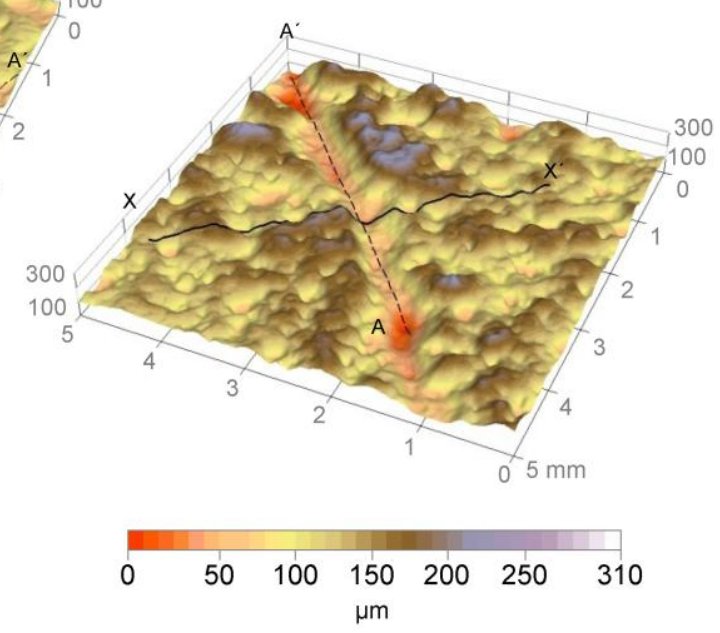


Figure 6.

E09

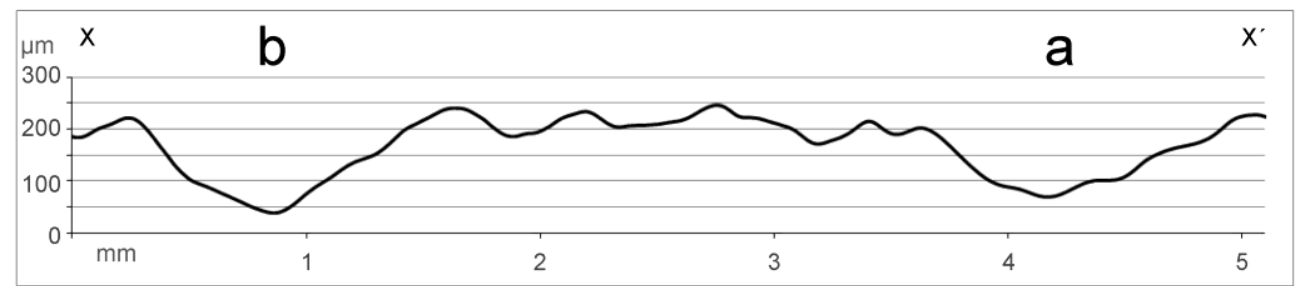

E10

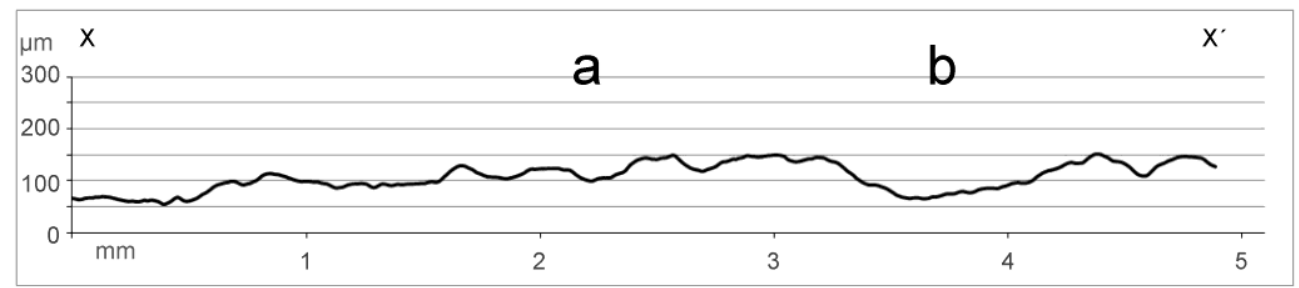

E35

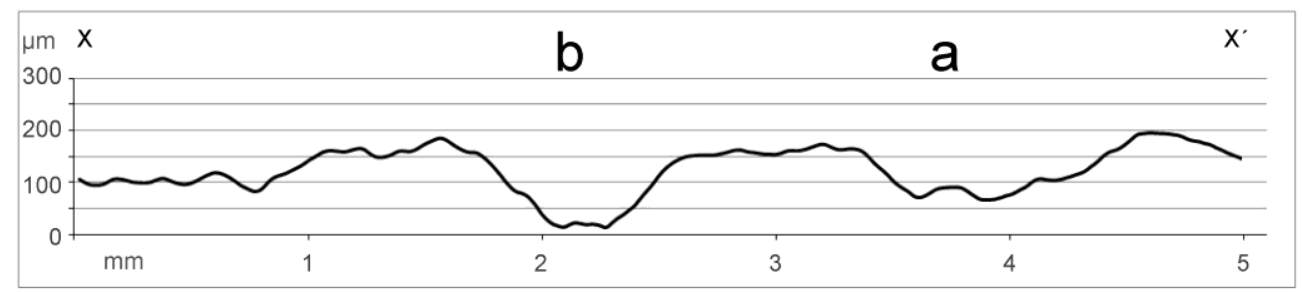

E46

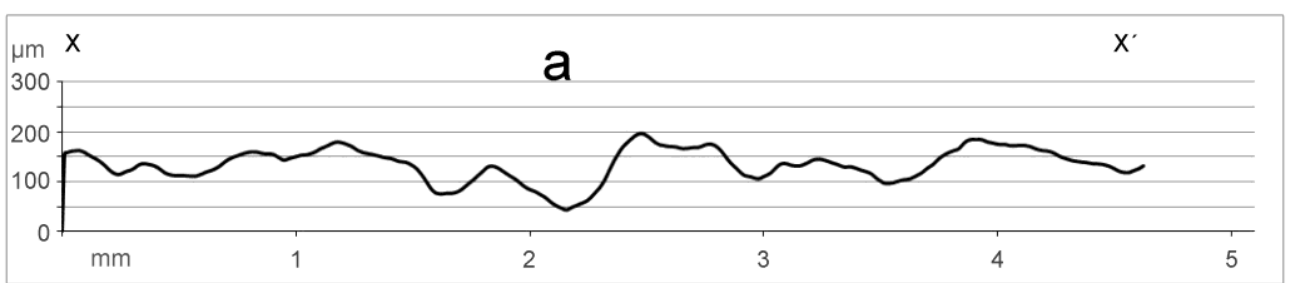


Figure 7.

E09-A

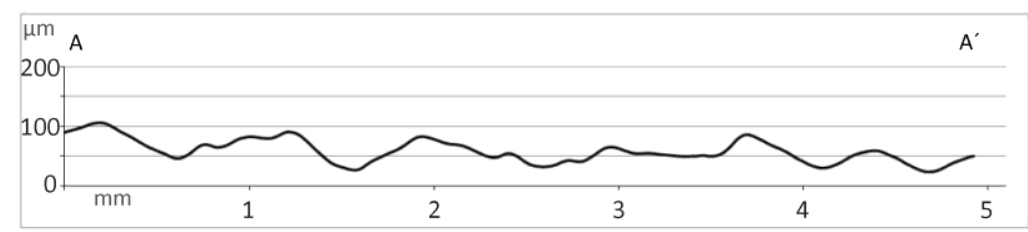

E09-B

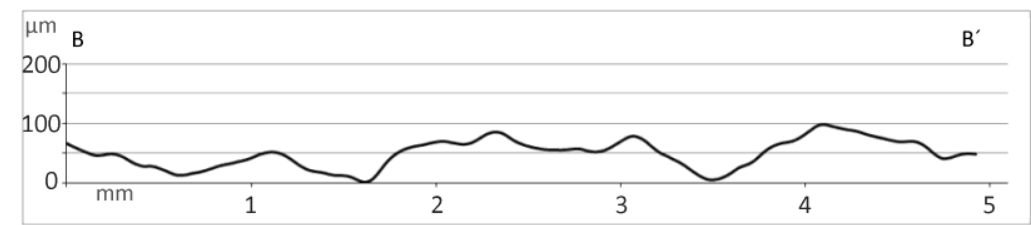

E10-A

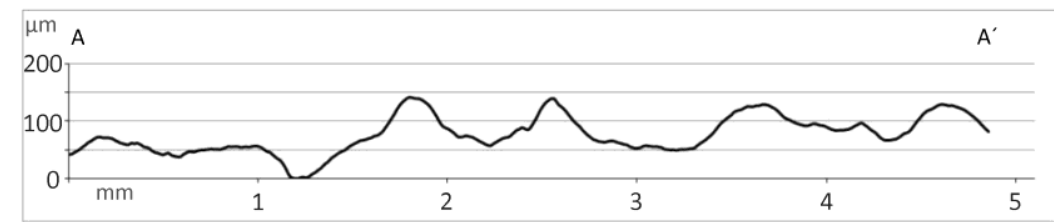

E10-B
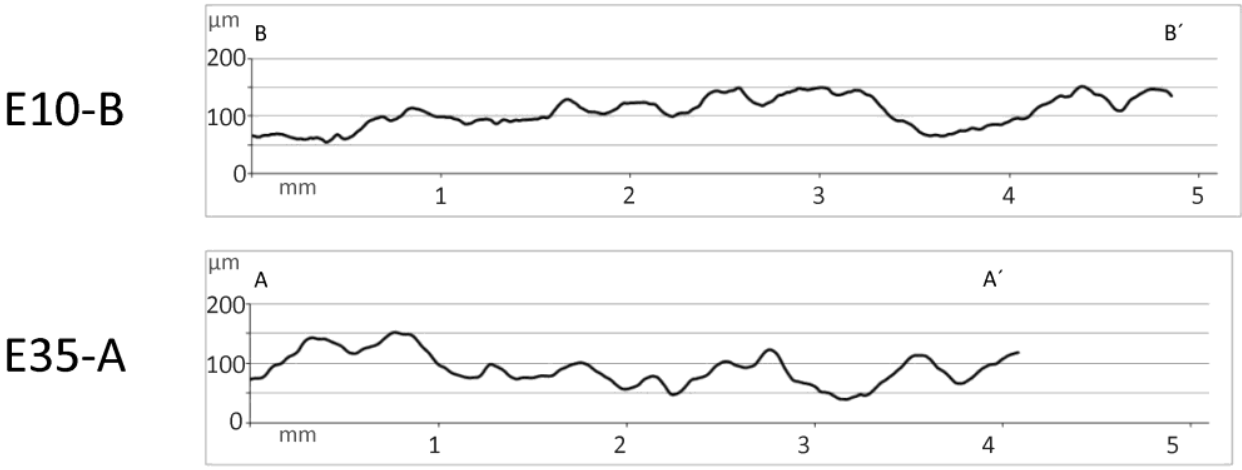

E35-B

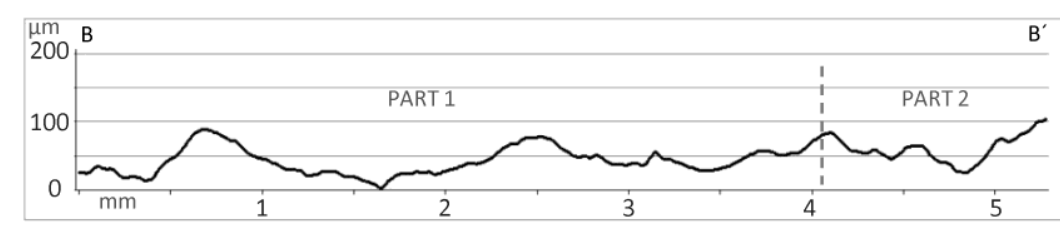

E46

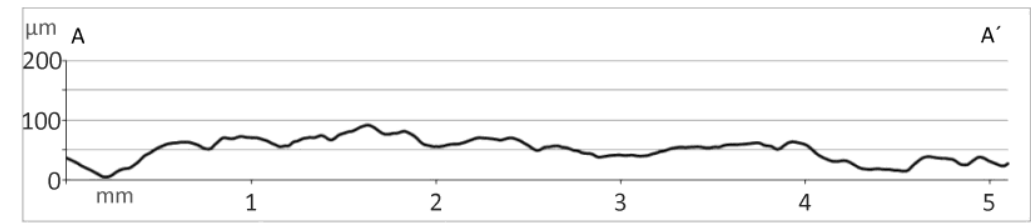


Figure 8.
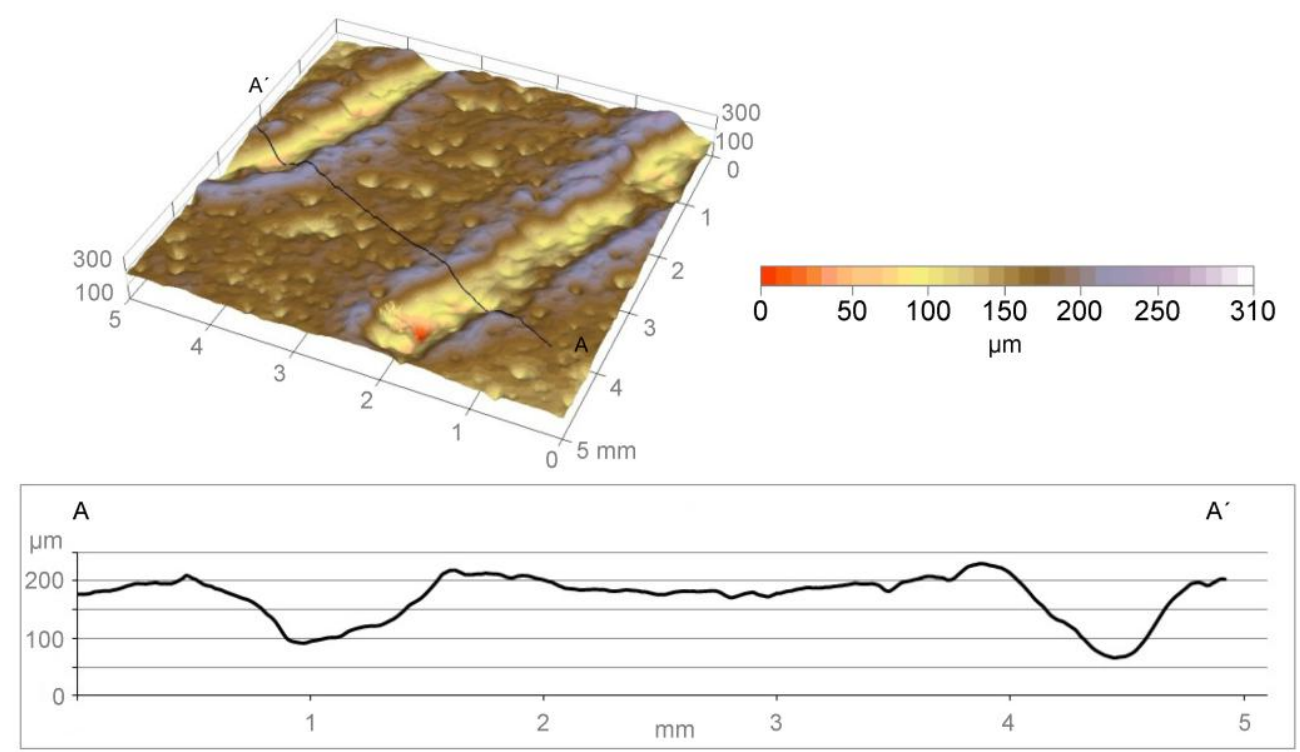
Table 1.

\begin{tabular}{|c|c|c|c|c|c|c|c|}
\hline & & & $\mathrm{L}^{*}$ & $a^{*}$ & $\mathrm{~b}^{*}$ & WI & YI \\
\hline \multirow{4}{*}{$\begin{array}{l}\text { Sculpture } \\
\text { surface }\end{array}$} & \multirow[b]{2}{*}{ Carved } & Mean & 76.4 & 3.7 & 18.0 & -9.3 & 29.5 \\
\hline & & Std & 2.0 & 1.0 & 1.1 & 2.2 & 1.3 \\
\hline & \multirow[b]{2}{*}{ Fractured } & Mean & 73.5 & 3.2 & 16.3 & -7.0 & 28.9 \\
\hline & & Std & 3.2 & 0.6 & 1.9 & 6.3 & 3.2 \\
\hline \multirow{6}{*}{$\begin{array}{l}\text { Surface site } \\
\text { fragment } \\
\text { (E00) }\end{array}$} & \multirow[b]{2}{*}{ Carved } & Mean & 57.5 & 3.5 & 16.7 & -10.5 & 35.1 \\
\hline & & Std & 5.9 & 0.5 & 1.4 & 2.7 & 2.1 \\
\hline & \multirow[b]{2}{*}{ Fractured } & Mean & 61.9 & 4.6 & 20.1 & -17.4 & 39.6 \\
\hline & & Std & 11.1 & 0.7 & 2.0 & 5.7 & 5.4 \\
\hline & \multirow[b]{2}{*}{ Sawn } & Mean & 77.0 & 2.8 & 15.5 & -3.3 & 26.8 \\
\hline & & Std & 2.8 & 0.8 & 1.9 & 7.0 & 3.6 \\
\hline
\end{tabular}

Table 2.

\begin{tabular}{|l|l|l|l|l|l|}
\hline Sculpture & & $\mathrm{Ra}$ & $\mathrm{Rq}$ & $\mathrm{Rz}$ & $\mathrm{Hp}$ \\
\hline \multirow{2}{*}{ 009 } & No marks & $8.1 \pm 1.6$ & $10.2 \pm 1.9$ & $33.9 \pm 6.0$ & 133 \\
\cline { 2 - 6 } & Marks & $9.1 \pm 1.5$ & $11.3 \pm 1.7$ & $33.3 \pm 4.7$ & 196 \\
\hline \multirow{2}{*}{ 10 } & No marks & $7.1 \pm 1.1$ & $8.8 \pm 1.4$ & $29.6 \pm 4.4$ & 140 \\
\cline { 2 - 6 } & Marks & $\mathbf{8 . 7} \pm 1.3$ & $\mathbf{1 0 . 9} \pm 1.6$ & $\mathbf{3 5 . 3} \pm 5.3$ & 108 \\
\hline \multirow{2}{*}{ E35 } & No marks & $7.8 \pm 1.3$ & $9.6 \pm 1.6$ & $30.7 \pm 5.3$ & 118 \\
\cline { 2 - 6 } & Marks & $\mathbf{9 . 5} \pm 1.6$ & $\mathbf{1 2 . 0} \pm 2.0$ & $\mathbf{3 8 . 5} \pm 5.8$ & 185 \\
\hline \multirow{2}{*}{ E46 } & No marks & $6.4 \pm 1.8$ & $8.4 \pm 2.4$ & $27.7 \pm 7.3$ & 152 \\
\cline { 2 - 6 } & Marks & $\mathbf{1 0 . 4} \pm 1.7$ & $\mathbf{1 2 . 9} \pm 2.1$ & $\mathbf{4 1 . 4} \pm 7.0$ & 143 \\
\hline
\end{tabular}

Table 3.

\begin{tabular}{|l|l|l|l|l|l|}
\cline { 3 - 6 } \multicolumn{2}{c|}{} & depth $(\mu \mathrm{m})$ & & width $(\mathrm{mm})$ & \\
\hline \multirow{2}{*}{ Sculpture } & Marks & Mean & Std & Mean & Std \\
\hline \multirow{2}{*}{ E10 } & A-A' & 237.5 & 16.0 & 1.2 & 0.1 \\
\cline { 2 - 6 } & B-B' $^{\prime}$ & 240.6 & 15.0 & 1.2 & 0.2 \\
\hline & A-A' & 150.1 & 27.3 & 0.7 & 0.1 \\
\hline & B-B' & 106.3 & 24.1 & 0.5 & 0.1 \\
\hline E35 & A-A' & 135.1 & 15.3 & 0.7 & 0.1 \\
\cline { 2 - 6 } & B-B' & 100.4 & 15.2 & 0.7 & 0.1 \\
\hline E46 & A-A' & 142.2 & 27.0 & 0.5 & 0.0 \\
\hline
\end{tabular}

